\title{
Memory
}

The Brazilian Journal of Infectious Diseases (BJID) could not let the year of 2004 come to an end without paying a just tribute to the memory of one of the greatest specialists in our field, Dr. Ricardo Veronesi, whose death at the beginning of this year orphaned Infectious Diseases in Brazil.

And who better than a disciple to pay homage to his master? We therefore copy here the beautiful, moving tribute written by Dr. Roberto Focaccia, one of the followers of the honorable figure that was Dr. Veronesi, and a pupil who has given continuity to his master's work and teachings.

\section{Tribute to a Master}

by Roberto Focaccia*

During the more than 30 years in which I had the privilege of knowing Professor Veronesi, I received lessons from him both on science and on life that permitted me to comprehend the profoundness of his critical sense, his enthusiasm and the passion with which he dedicated himself to humanity throughout his career as a physician and university professor.

The Master would propose great theses; he would bring the principal medical and social problems of the time into debate. Both in the university and in his politics (in truth, bad politics), he chose paths that were in total opposition to my convictions but his sincerity and the impetus with which he defended them never failed to earn my profound admiration.

He defended ideas that were ahead of his time: he supported birth control. He defended the end of the academic dictatorship of his university, attracting the displeasure of those who benefited from it. He wanted the international pharmaceutical industry to become an integral part of research in Brazil. He supported the legalization of abortion and by doing so attracted a violent reaction from the clergy. He defended a compulsory basic vaccination program because he could not comprehend the blindness of the health sector administrators, and this earned him the enmity of many, minor scientists encroached in the cogs of the governmental machine.
Dr. Veronesi initiated his medical career by specializing in Virology in the United States. He returned to Brazil where he chose antiviral vaccines as his field of research. He later went on to concentrate his attention on tetanus and made an enormous contribution to the study of this pathology. He founded the International Tetanus Society, which has its headquarters in Lyon, France, and he gained the respect of the World Health Organization and of the global scientific community.

In 1980, he founded the Brazilian Society of Infectious Diseases. Through his work and leadership, he sought to create an alternative association to that of Tropical Medicine, which, since the latter encompassed essentially only the major Brazilian endemias, it stubbornly refused to make room for the neglected field of clinical infectious diseases. He was the first President of the Society, and succeeded with great effort in overcoming skepticism and prejudice to set up what today has grown to become the solid society known as the SBI (Sociedade Brasileira de Infectologia).

As consultant to the US Academy of Science and member of the editorial board of numerous peerreviewed journals, Dr. Veronesi outlined paths for many of his pupils, established a school, published books in Brazil and abroad, and put together one of the most extensive curricula in Brazilian academia. 
Curiously, however, he kept secret the fact that he considered the major accomplishment of his life to have been the authorship of a law that made the antitetanic vaccine obligatory in nursery schools. He flaunted a winner's vanity but, just as every human being, he was pleased by even those small acts of greatness that he was able to offer society. That was what I most admired in my Master. He taught me the ways of science and rewarded me with his intelligence, his striking, impulsive, humane personality. No one was indifferent to the Master: he was deified by some, while hated by others. Veronesi was controversial, which was what he wanted to be.

He was extremely criticized for his right-leaning politics. Many kept their distance from him because of the unfair label he received as a "pawn of the right". In his time, he succeeded in the apparent contradiction of sticking to the right while fighting against injustice and social inequality. Such accusations, however, hurt him greatly and may have been the moving force that impelled him to go on to higher scientific circles abroad where his merits would be recognized.

Professor Emeritus of the University of São Paulo, he received the title of Professor Honoris Causa at renowned universities abroad and was honored and celebrated at the great scientific centers around the world, receiving the highest and most deserved accolades. During our travels through the great research centers of the world, I was witness to how renowned and respected he was. I listened to scientific debates between the Master and the great names of the scientific world. Veronesi would make propositions that would frequently capture the enthusiasm of his listeners.

We worked together with the great names of the scientific world in many, many research projects at a time in which research was not linked to nor ordered by the marketing departments of the large pharmaceutical companies. During our travels around the world, I was proud to make the acquaintance of famous figures such as Sabin, Salk, Frenkel, Krugman, Gadusek, Trepo, Cvetanovic, Masur, Gallo, Montagnier, Fauci, Rizzetto, Blumberg, Bizzini, Kryzanovski, Yamaguchi and many other exponents of the field of Infectious Diseases. That was my Master. That's how geniuses are. Professor Veronesi was an extraordinary man who brought honor to our science and left a space that will never be filled. A citizen of Humanity.

(*) Specialist in Infectious Diseases and Full Professor of the School of Medicine, University of São Paulo. Coordinator of the Hepatitis Group at the Hospital Emilio Ribas. Founding member and vice president of the SBI. Together with Ricardo Veronesi, he is co-author of numerous articles and books, among them the Textbook of Infectious Diseases, winner of the Jabuti Prize in 1997. The full text of this tribute can be found on the SBI's Internet site: www.infectologia.org.br. 